Jolanta Żelazna

Uniwersytet Mikołaja Kopernika, Toruń

ORCID: 0000-0003-0588-4848

e-mail: jot_zna@umk.pl

\title{
Jean-Jacques Rousseau: „rozum jakiś odmienny, innego rodzaju"*
}

Tytułowa fraza rozum jakiś odmienny, innego rodzaju może sugerować, że w niniejszym artykule chodzić będzie o wielokrotnie już podnoszoną kwestię Russowskiej krytyki postępu w dziejach człowieka, kultury i cywilizacji, postępu zainicjowanego przez rozum (raison, łac. ratio). Jednak głównym, jak sądzę, przedmiotem uwagi Rousseau nie była ta raison ani jej tak użyteczne funkcje, jak np. refleksja (réflexion, odbijanie $\mathrm{w}$ języku bezpośrednich doświadczeń ciała), różne typy wnioskowań, abstrahowanie czy porównywanie, lecz odsunięty przez nią w cień i zdeprecjonowany rozum jakiś odmienny, innego rodzaju. Dopiero te dwa rodzaje rozumności, pielęgnowane i „żywione” w stosowny dla każdego z nich

* Jean-Jacques Rousseau, Wyznania, t. 1, przeł. i wstępem poprzedził Tadeusz Żeleński (Boy) (Warszawa: PIW, 1956), 68; cytuję jako: Wyznania. Zob. Jean-Jacques Rousseau, Les Confessions, Texte du manuscrit de Genève (1782), Édition du groupe «Ebooks libres et gratuits», 7: „Ces émotions confuses, que j'éprouvais coup sur coup, n'altéraient point la raison que je n'avais pas encore ; mais elles m'en formèrent une d'une autre trempe, et me donnèrent de la vie humaine des notions bizarres et romanesques, dont l'expérience et la réflexion n'ont jamais bien pu me guérir", dostęp 24.03.2021, https://www.google.com/search?q=JeanJacques+Rousseau $\% 2 \mathrm{C}+$ Les+Con fessions $\% 2 \mathrm{C}+$ Texte $+\mathrm{du}+$ maniscrit+de+Gen $\% \mathrm{C} 3 \%$ A $8 v e+(1782) \% 2 \mathrm{C}+\% \mathrm{C} 3 \% 89$ dition $+\mathrm{d}$ u+groupe+\%C2\%ABEbooks+libres+et+gratuits $\%$ C2\%BB\&oq=JeanJacques+Rousseau $\% 2 \mathrm{C}+$ Les+Confessions $\% 2 \mathrm{C}+$ Texte+du+maniscrit+de+Gen $\% \mathrm{C} 3 \% \mathrm{~A} 8 \mathrm{ve}+(1782) \% 2 \mathrm{C}+\%$ C3\%89dition+du+groupe+\%C2\%ABEbooks+libres+et+gratuits $\%$ C2\%BB\&aqs=chrom e.69i57.7900814j0j1\&sourceid=chrome\&ie=UTF-8. 
sposób, tworzą zdaniem Rousseau podstawę pełnego człowieczeństwa, zarówno Emila, jak i Zofii.

Pobieżny szkic tego „odmiennego rozumu” można rozpoznać w migawkach z życia człowieka natury zapisanych w Rozprawie o pochodzeniu nierówności ${ }^{1}$. Bardziej szczegółowe instrukcje właściwego obchodzenia się z tą źródłową postacią naszego rozumu znajdziemy w Emilu, przy czym Rousseau nie próbuje znaleźć dla niej nazwy, pozwalającej odróżnić go od późniejszego, bardziej wyrafinowanego i abstrakcyjnego rozumującego rozumu refleksyjnego. O tym, czym miałby być rozum innego rodzaju, co odróżnia go od ikonicznego dla epoki rozumu (raison), więcej można dowiedzieć się z Wyznań. Tutaj właśnie pojawia się fraza rozum jakiś odmienny, innego rodzaju i ujawnia się jej sens, raczej dany do zrozumienia niż sprecyzowany jasno ${ }^{2} \mathrm{w}$ opowieści o pewnym przełomowym wydarzeniu, przedwcześnie kończącym etap dzieciństwa Jeana-Jacquesa.

Sądzę jednak, że w trzech wymienionych wyżej perspektywach: społeczno-dziejowej (Rozprawa), antropologiczno-pedagogicznej (Emil $\left.{ }^{3}\right)$ i osobistej (Wyznania) Rousseau dotyka tej samej kwestii, mianowicie uporczywej (jeśli nie wręcz programowej dla swej epoki) deprecjacji dyspozycji umysłu, źródłowej dla pełni człowieczeństwa. Dyspozycję tę można by nazwać holistycznym rozumem intuitywnym, zdolnością bezpośredniego (bezrefleksyjnego) rozumienia, dokonującego się $\mathrm{w}$ jednym akcie całościowego pojmowania (entendre). O zasadności takiej interpretacji przekonuje podejście hermeneutyczne, pozwalające szukać rozwiązań zawiłych fragmentów teorii w biografii jej twórcy, a w tym przypadku - oświetlić szkice koncepcji naturalnego umysłu z Rozprawy i pierwszych ksiąg Emila tekstem z Wyznań.

Tyrady Rousseau przeciw postępowi, cywilizacji, moralności i pozostałym wynalazkom, dzięki którym formuje się obywatela, obniżyły wagę tych szkiców w oczach czytelników. Zapisane w Rozprawie o podstawach i pochodzeniu nierówności między ludźmi stwierdzenie, „że

${ }^{1}$ Jean-Jacques Rousseau, Rozprawa o podstawach i pochodzeniu nierówności między ludźmi, w: Trzy rozprawy z filozofii społecznej, przeł. i oprac. Henryk Elzenberg, PWN, Warszawa 1956, cytuję jako: Rozprawa.

${ }^{2}$ Niejasność francuskiego tekstu cytowanego w powyższym przypisie skłoniła np. wydawców angielskiego przekładu Wyznań do pominięcia całej frazy o „innym” rozumie: „This confused succession of emotions did not retard the future efforts of my reason, though they added an extravagant, romantic notion of human life, which experience and reflection have never been able to eradicate". The Confessions of Jean Jacques Rousseau, Complete By Jean Jacques Rousseau (In 12 books) Privately Printed for the Members of the Aldus Society London, 1903, Book I; dostęp 24.03.2021, https:// www.gutenberg.org/files/3913/3913-h/3913-h.htm.

${ }^{3}$ Jean-Jacques Rousseau, Emil czyli o wychowaniu, t. 1, przeł. Wacław Husarski (Wrocław: Zakład im. Ossolińskich Wydawnictwo Polskiej Akademii Nauk, 1955), 2. 
refleksyjność (réflexion ${ }^{4}$ ) jest stanem przeciwnym naturze i że człowiek, który rozmyśla (médite), to zwierzę zwyrodniałe" ${ }^{2}$, budziło sprzeciw jako radykalnie sprzeczne z określeniami natury i istoty człowieczeństwa ugruntowanymi $w$ religii, sztuce i filozofii. Takiej oceny rozumu nie wzmacniało przy tym zastrzeżenie Rousseau, że obserwacji człowieka „naturalnego" nie sposób przeprowadzić we współczesnych społeczeństwach i że próżno go szukać na nowo odkrywanych lądach, gdzie dotąd nie znaleziono ludzi żyjących $\mathrm{w}$ stanie przedspołecznym ${ }^{6}$. Pomysł, aby zaprzątać uwagę czytelników wydumanym stanem naturalnym hipotetycznej inteligentnej, lecz bezrefleksyjnej istoty ludzkiej, odbierany jako oburzający, okazywał się ponadto bezzasadny.

Na konkursowe pytanie Akademii Rousseau odpowiedział własnym pytaniem: „jakże bowiem rozpoznać źródło nierówności między ludźmi, nie zaczynając od poznania ich samych?"' , zupełnie jakby nie przyswoił sobie albo za nic miał całą wiedzę o człowieku, zarówno zgromadzoną przez tradycję, jak i tę najnowszą, dostarczaną przez współczesnych mu badaczy, odkrywców i myślicieli. A przecież, jak zaznaczył w Wyznaniach, zanim zabrał się za Rozprawę, zdążył wpierw starannie przestudiować dzieła Platona, Arystotelesa, stoików, autorów renesansu i prekursorów nowej filozofii, nie wyłączając Logiki Arnaulda i Nicole'a, pism Descartes'a, Malebranche'a, Pascala, Leibniza czy Locke'a ${ }^{8}$. Czyżby autorzy ci nie wiedzieli o czymś, co istotnie powinno zmienić utarty pogląd na naturę ludzką?

„Widzę rzeczy inaczej niż inni ludzie; dawno mi to zarzucono"9 stwierdził Rousseau w Emilu i podobną uwagę zapisał też w Wyznaniach:

4 Terminy francuskie do cytatów z Rozprawy o podstawach $i$ pochodzeniu nierówności między ludźmi Rousseau wprowadzam na podstawie: Jean-Jacques Rousseau, Discours-sur-l-origine-et-les-fondements-de-l-inegalite..., (tu: p. 23), dostęp 21.02.2021, http://www.livrespourtous.com/e-books/detail/Discours-sur-l-origine-et-lesfondements-de-l-inegalite.../onecat/Livres-electroniques+Auteurs+R-a-Z+Rousseau,Jean-Jacques/0/all_items.html.

5 Rozprawa, 149.

${ }^{6}$ Kontrprzykładem nie może być postać Robinsona Crusoe, który znalazł się w stanie natury, przybywając na niezamieszkaną wyspę z wysoko rozwiniętego społeczeństwa i za wszelką cenę dążył do powrotu do cywilizacji. Rousseau znał i bardzo cenił Przypadki Robinsona Crusoe Daniela Defoe, a lekturę tę jako jedną z pierwszych i nielicznych zalecał do przeczytania modelowemu wychowankowi (zob. Emil, t. 1, 225).

${ }^{7}$ Jean-Jacques Rousseau, Przedmowa do Rozprawy o podstawach i pochodzeniu nierówności między ludźmi, w: Trzy rozprawy z filozofii społecznej, 127.

8 Wyznania, t. 1, 339 i nast. Wspomniane tu studiowanie klasyków filozofii nie wiązało się z regularną edukacją akademicka, której Rousseau nigdy nie odbył, polegało raczej na samodzielnych lekturach, notatkach i przemyśleniach.

9 Emil, t. 1, 5. 
Zacząłem wcześniej czuć niż myśleć - to wspólna dola ludzkości. Doświadczyłem jej bardziej niż ktokolwiek. [...] posiadłem w krótkim czasie nie tylko nadzwyczajną łatwość czytania i rozumienia, ale także niezwykłą na mój wiek inteligencję uczuć (une intelligence sue les passions). Nie miałem najmniejszego pojęcia o rzeczach, kiedy wszystkie uczucia były mi znajome. Nic nie pojmowałem jeszcze, a wszystko już czułem. Te mgliste wzruszenia nie zamąciły mi rozumu (raison), którego jeszcze nie miałem, ale stworzyły we mnie rozum jakiś odmienny, innego rodzaju, i dały mi o życiu ludzkim dziwaczne i romantyczne pojęcia, z których doświadczenie i refleksja nigdy mnie nie zdołały zupełnie wyleczyćn ${ }^{10}$.

Jak to się dzieje, że inteligencja uczuć bądź rozum jakiś odmienny, innego rodzaju niż raison, o której powiadaja, że jest najsprawiedliwiej rozdzielona, skoro nikt nie uskarża się na jej brak, nie jest bynajmniej pospolitą cechą wśród ludzi dorosłych? Inteligencję tę Rousseau przypisuje co prawda wszystkim dzieciom - czuć wcześniej niż myśleć to wspólna dola ludzkości - ale też jest pewien, że zanim dziecku udaje się poznać i przeżyć uczucia w ich wzajemnych związkach, wychowanie narzuca na tę szczególną postać rozumu nieprzeniknioną zasłonę. Właściwiej byłoby powiedzieć, że wtrąca ją do lochu i zatrzaskuje za nią drzwi, gdyby wspomniana przez Rousseau w Wyznaniach wychowawcza ingerencja w umysły dzieci była jakąś regułą i zawsze przebiegała według opisanego tam schematu. Zanim jednak przybliżymy jej znaczenie, wypada przypomnieć, kim według Rousseau jest dziecko i jak staje się ono człowiekiem.

Arcydziełem dobrego wychowania jest wytworzenie człowieka rozumnego (un homme raisonnable ${ }^{11}$ ): jakże więc chcieć wychować dziecko za pomocą rozumu (raison)! Znaczy to zaczynać od końca, znaczy to chcieć z narzędzia uczynić to, co za pomocą narzędzia tego ma być wykonane. Gdyby dzieci pojmowały rozumowanie (entendaient raison), zbyteczne byłoby wychowywanie ich; ponieważ nie pojmują go, przeto przemawiając do nich od najwcześniejszego wieku językiem, którego nie rozumieją (n'entendent), przyzwyczaja się je do nadużywania słów, do sprawdzania wszystkiego, co się im mówi, do uważania się za równie mądrych jak nauczyciel, do rozprawiania i uporu; a to, co się chce osiągnąc za pomocą rozumowania (par des motifs raisonnables), osiagga się jedynie przez pobudzenie pożądliwości lub strachu, lub próżności, którymi obok rozumowania zmuszonym się jest zawsze posługiwać ${ }^{12}$.

Skoro zwykle wychowanie "zaczyna się od końca”, a dziecko zdolne jest do pojmowania (entendre) uczuć, lecz nie do rozumowania, to

10 Wyznania, t. 1, 68-69, kursywa w cytacie polskim - J.Ż.

11 Rousseau, Émile ou de l'education, 54.

12 Emil, t. 1, 84-85. 
jak właściwie należałoby zacząć „od początku”? W Emilu czytamy, że wychowanie człowieka zaczyna się, zanim przyjdzie on na świat. Już wtedy rodzice wybierają dla niego "model wychowania” i mogą zdecydować, komu powierzą zadanie ukształtowania w dziecku podstawy szczęśliwego życia. Należy jednak pamiętać, że bez względu na ten wybór w wychowaniu człowieka zawsze bierze udział trzech nauczycieli: natura, rzeczy w otoczeniu i ludzie ${ }^{13}$. Największym szczęściem dla wychowanka byłaby zgodność i współdziałanie wychowawcy z przyrodą i naturalnym biegiem rzeczy, gdyż tak prowadzony, nie doświadczyłby u początku życia sprzeczności w sobie ani oporu i buntu wobec ludzi, rzeczy i porządku natury. Ten ostatni pozwala nam przyjść na świat bez sił i środków do zaspokojenia jedynej na szczęście potrzeby: przetrwania, o które zatroszczą się ludzie. Wyposażeni w miłość siebie samych (amour de soi), zaczniemy rozwijać wiedzę o sobie i rzeczach najbliższego otoczenia, z początku traktując opiekunów tak samo jak rzeczy. Jednakże "rodzimy się wrażliwi"14 i w relacjach z rzeczami i ludźmi ta nasza zdolność czucia pozwoli nam nauczyć się przeżywania i odróżniania przyjemności i przykrości, zadowolenia i niespełnienia potrzeb.

Wychowując człowieka, należy pamiętać, że natura rozwija w nas rozum (raison) stosownie do wzrostu sił ciała, dlatego niemowlę go nie potrzebuje, a małe dziecko jednego i drugiego ma niewiele. Najtrudniejszą pracą wychowawcy na tym etapie jest powstrzymywanie się od działania: nie należy krępować ciała dziecka niewygodnym i zbędnym odzieniem, śpieszyć mu z pomoca, jeśli samo potrafi zaspokoić swe potrzeby, trzeba natomiast być głuchym na żądania, za którymi nie stoją potrzeby naturalne i nie pozwolić na to, by stać się niewolnikiem dziecięcych kaprysów. Wytrzymałość psychofizyczną zapewni dziecku przyzwyczajenie go do zmian: skoro przez „naturę" filozofowie i liczne autorytety chcą rozumieć nawyk ${ }^{15}$, niechże Emil nawyknie do tego, że życie jest nieustanną zmiana, a wówczas nie będzie odczuwać lęku ani przywiązania wobec rzeczy, na które nikt z nas nie ma wpływu.

Dzieciństwo trwać będzie do około dwunastego roku życia wychowanka. W tym czasie zadaniem wychowawcy będzie takie pokierowanie dzieckiem, aby mogło ono doświadczać napięcia między swoją wolą a siłami fizycznymi i wiedza, jaką zgromadziło o sobie, rzeczach i porządku natury. Składa się na nią samowiedza: o odczuciach ciała i ich zmienności, o doświadczanych uczuciach, o własnej sile, pamięci i zdobytych umiejętnościach, a oprócz niej także wiedza o własnościach rzeczy i cykliczności w naturze. Dziecko zdobywa tę wiedzę na drodze doświadczenia torowanego przez spontaniczną ciekawość, ukierunkowaną

\footnotetext{
13 Tamże, 9.

14 Tamże, 10.

15 Tamże.
} 
przez wychowawcę. Na tym etapie, gdy ciało dziecka nie rozwinęło jeszcze pełni sił i wzrostu, pierwotna zdolność jego umysłu (esprit) - rozumienie czy też pojmowanie (entendre) - ma zostać skierowana ku poznaniu ograniczeń, jakich doświadcza wola w stosunku do możliwości jej zaspokojenia. Utrwalenie tego doświadczenia: „wprawdzie pragnę, ale nie mogę" stanie się podstawą poczucia stosowności powściągania woli, aby na następnym etapie życia zdolna była kierować się tylko ku tym celom, które są naturalnie osiągalne. W ten sposób kształtuje się człowieka wolnego, respektującego "od zawsze" bez buntu i przymusu naturalną konieczność i porządek rzeczy.

Siła rozumu (raison), w tym także rozumu refleksyjnego (la raison réflexive), zdolnego porównywać i na tej podstawie sądzićć, rozwinie się wraz z rozwojem ciała, jego potrzeb i coraz większych możliwości samodzielnego ich zaspokajania. W późnym dzieciństwie, u progu młodości Emil myśli prosto, ale jasno, a jego wykształcenie (umiejętność czytania, rachowania, pisania) ograniczy się do spraw, z którymi będzie miał praktycznie do czynienia. Gotów jest wkroczyć w wiek, kiedy wzrost i siły ciała zaczną się zmieniać, a umysł (l'esprit) z wolna zapragnie zwiększać zasoby wiedzy płynącej z doświadczenia. Zadaniem wychowawcy będzie wówczas skierowanie uwagi chłopca na pożytek z każdego nowego doświadczenia - „na co się to może przydać?"17, a przy okazji na poszerzenie pola jego ciekawości. Rousseau podkreśla też, że nie należy kierować uwagi dziecka na to, czego „nie może widzieć" ${ }^{18}$, ponieważ nie pozwala mu na to jego doświadczenie: sprawy ludzi dorosłych będą dla jego umysłu niezrozumiałe ${ }^{19}$, „niestrawne”, tak jak potrawy dorosłych są niestrawne dla niemowląt. Wprowadzanie dziecka w relacje społeczne dokonywać się może przez ukazywanie mu pożytku z rozmaitych prac, jakie wykonują ludzie. Odpowiada się tym samym na pytanie o pożytek różnych narzędzi i umiejętności, ukazuje zasady wymiany świadczeń i dóbr i rozwija zdolność porównywania, będącą zaczątkiem rozumowania (raisonnement). Przyda się ono, gdy dziecko odkryje siłę pytania „dlaczego jest tak, a nie inaczej” i będzie stosować je zarówno do zjawisk przyrody, jak i urządzeń świata ludzkiego. Pozwoli mu ono budować sądy ${ }^{20}$ porządkujące pamięć i wytyczające ścieżki doświadczenia. Porównywanie i sądzenie, funkcje rozumu refleksyjnego, będą rozwijały się w odniesieniu do obserwacji pracy ludzkiej i dostarczą materiału do

16 Zob. Emil, t. 2, 93.

17 Tamże, t. 1, 217.

18 Tamże, 224.

19 „Nie mogąc podnieść go do poziomu człowieka dorosłego, obniż dlań człowieka dorosłego do poziomu dziecka". Tamże. Przykładem takiego zabiegu jest ukazanie losów Robinsona Crusoe na bezludnej wyspie.

20 "Sztuka sądzenia i sztuka rozumowania [porównywania jednego wrażenia z drugim - przyp. JŻ] są dokładnie jednym i tym samym". Tamże, 259. 
coraz liczniejszych rozmyślań (pensees). Staną się one niezbędne, aby siły rozumu, wyprzedziwszy w ten sposób przyrost sił ciała, stały się wędzidłem zdolnym powściągać wolę młodzieńca.

Koncepcja stworzona przez Rousseau nie odmawia dzieciom rozumu (raison), a jednak znajdujemy w niej sformułowania niedwuznacznie wskazujące, że nie będąc dorosłym, "skończonym”, czyli w pełni rozwiniętym cieleśnie i umysłowo człowiekiem, dziecko nie jest zdolne dokonywać czynności rozumowych ${ }^{21}$ (raisonnement). Rozwój jego umysłu (l'esprit) należałoby objaśniać przez analogię do rozwijania zwoju tekstu, a nie przerzucania kartek książki: treść, zawartość ujawnia się wraz z rozwijaniem wstęgi i tak jak nie sposób w takiej lekturze przeskoczyć rozdziału albo dwóch, tak samo trudno będzie cofnąć się do miejsca, gdzie zapisano informacje, które nam umknęły. Tymczasem kształtując umysły ludzkie, najczęściej dopuszczamy się zbrodni na samej naturze, rozcinając "zwój" umysłu na kartki i niecierpliwie przerzucając je w przód i w tył w nadziei, że taka lektura przynieść może oczekiwane owoce. Czysta tablica dziecięcego umysłu najwyraźniej nie jest podzielona nawet na rubryki, w których doświadczenie rozdziela się i zapisuje osobno wrażenia zmysłów, uczucia, słowa, ich znaczenia itd. Opisywane przez Rousseau wychowanie Emila ujawnia raczej Hume'owski strumień umysłu, coraz szerszy i głębszy, płynący coraz żywiej wraz z wiekiem dziecka niż pustą kartę Locke'a. Chłopięce (puer) doświadczenie Emila jest wciąż jeszcze holistyczne, w każdej chwili ",jedno" i całe, dopóki jego umysł nie nauczy się reflektować, to znaczy patrzeć na rzeczy i siebie oczyma Innego. Oby nie został do tego zmuszony przedwcześnie! ${ }^{22}$

A jeśli tak się stanie?

Wspominając "pierwsze ślady życia uczuciowego" ${ }^{23}$ i opisując zamęt, jakiego będąc dziesięciolatkiem doświadczył w efekcie chłosty wymierzonej mu przez córkę pastora Lambercier ${ }^{24}$, Rousseau stwierdził:

${ }^{21} \mathrm{Z}$ tego samego powodu dziecko będące stroną procesu sądowego nie ma władzy dokonywania czynności prawnych i musi być reprezentowane przed sądem przez osobę dorosła, do takich czynności zdolną. Mimo tych oczywistości wychowawcy zalecają dzieciom lektury, których treść daleko wykracza poza dziecięce doświadczenie. Uczeń zapamiętuje brzmienie nowych słów i zwrotów, ale nie znając ich realnych znaczeń i nie rozumiejąc kontekstu ich użycia, będzie je zaledwie reprodukował (powtarzał), a nie posługiwał się nimi. Zob. dialog dziecka i nauczyciela w: Emil, t. 1, cz. 2, 85.

${ }^{22}$, ,[...] pozwól w dziecku dojrzewać dzieciństwu” przestrzega Rousseau, dodając: „Wiedz, że uczucia, które zrodzą się, zanim umysł może je osądzić, są niebezpieczne" (Emil, t. 1, 91).

${ }^{23}$ Wyznania, t. $1,79$.

${ }^{24} \mathrm{O}$ pobycie w Bossey Rousseau pisze w Wyznaniach, t. 1, s. 73-80. Kary fizyczne należały w domu pastora Lambercier do rzadkości; jego córka, trzydziestoletnia panna Lambercier, osoba miła i łagodna, zwykle radziła sobie z wybrykami 
"zmieniono by niewątpliwie metody postępowania z młodzieża, gdyby lepiej widziano najdalsze skutki owego pedagogicznego środka, stosowanego zawsze bez rozwagi, niekiedy bez miary" ${ }^{\prime 25}$. Jednakże nie to zdarzenie ilustruje moment, w którym wychowawcza ingerencja dorosłych złamała naturalną jedność ${ }^{26}$ duszy dziecka i odwracając kolejność przemian umysłu przepisaną przez naturę, wywołała w nim nieodwracalne szkody.

W relacji Wyznań tuż po rozważaniach o zamęcie uczuć i przedwcześnie rozbudzonych zmysłów pojawia się wstrząsające wspomnienie zajścia, którego przebieg i istota stają się udziałem większości, jeśli nie wszystkich dzieci „wyprowadzanych na ludzi” w kulturze Europy. Chyba ta właśnie wzmianka najdobitniej ilustruje Russowską koncepcję dziecięcej conscience ${ }^{27}$ czy rozumu jakiegoś innego, wcześniejszego, a być może źródłowego względem raison i réflexion, zdolnego pojmować

wychowanków bez stosowania przemocy. „Panna Lambercier, przywiązana do nas jak matka, miała i władzę matki i posuwała ją niekiedy, o ileśmy zasłużyli, aż do dotkliwej kary, zazwyczaj stosowanej u dzieci. Dość długo poprzestawała na groźbie, a ta groźba kary, całkiem mi nieznanej, przerażała mnie niezmiernie. Po egzekucji wszelako wydała mi się ona mniej straszna niż samo oczekiwanie; a co najosobliwsze, to iż kara ta przywiązała mnie jeszcze do osoby, z której rąk jej doznałem. Trzeba nawet było całej szczerości tego przywiązania i wrodzonej mej łagodności, aby mnie powstrzymać od pokusy powtórnego zasłużenia na tę karę; w tym bólu bowiem, we wstydzie nawet, znalazłem domieszkę zmysłowej rozkoszy, której wspomnienie, silniejsze od obawy, budziło we mnie chęć doznania jeszcze raz tych samych wzruszeń z jej ręki. [...] Ta recydywa [...] przyszła wreszcie bez mej winy, to znaczy bez mej woli; skorzystałem z niej, mogę rzec, ze spokojnym sumieniem. Ale ten drugi raz był zarazem ostatnim. Panna Lambercier, spostrzegłszy zapewne po jakimś objawie, że kara mija się z celem, oświadczyła, że rezygnuje z niej, jako zbyt dla niej nużącej. [...] Któż by uwierzył, że ta dziecinna kara, otrzymana przez ośmioletniego chłopca z rąk trzydziestoletniej panny, rozstrzygnęła o mych upodobaniach, pragnieniach, namiętnościach, o mnie całym, na całe życie, i to właśnie w kierunku przeciwnym temu, który, naturalnym sposobem, powinien by stąd wyniknąć?". Tamże, 75-76.

25 Tamże, 75.

${ }^{26}$ Dziecko od pierwszych swoich dni życia należy wciąż jeszcze do natury, z której jego wychowawcy wyprowadzają je ku stanowi społecznemu. Rousseau pisze w Emilu, że „,człowiek natury [...] jest jednością, całością bezwzględną" (tamże, 11), a dramat dziecka poddanego zwyczajowemu wychowaniu polega na sprzeczności jego naturalnego dążenia do życia dla siebie z dążeniem wychowawców, by ukształtować je z pożytkiem dla innych ludzi (tamże).

${ }^{27}$ Głównym, najczęściej wymienianym znaczeniem słowa conscience jest „sumienie". W omawianym tu kontekście odniesienie sumienia do dobra i zła zakłada zestawienie, porównanie i odróżnienie tych wartości, ma charakter refleksyjny. Rzadziej używane znaczenie conscience - świadomość - tak, jak opisuje ją Rousseau, śledząc jej przejawy już u niemowląt, nie może być stanem refleksyjnym (niemowlęta nie mogą reflektować odczuć w słowach języka), lecz raczej intuitywną bezpośrednią wiedzą o sobie, swoim stanie, doznaniach fizycznych i uczuciowych, wreszcie o zjawiskach spostrzeganych "bezzałożeniowo” (przedjęzykowo). W Emilu pojawia się "prawo sumienia” (une loi de la conscience), „wrodzona zasada” (un principe inné), „pierwszy 
(entendre), lecz jeszcze nie rozumować (raisonnement), a zarazem pokazuje skutki naruszenia zwykłej kolejności rozwijania się władz mentalnych człowieka. Sądzę też, że pozwala lepiej zrozumieć źródła Russowskiej „osobności” filozoficznej i rzuca nieco światła na ambiwalentny stosunek autora Emila do koncepcji wychowania rozwijanej przez Locke'a ${ }^{28}$.

Rousseau wspominał, że gdy pewnego dnia samotnie odrabiał lekcje w pokoju obok kuchni, służąca rozłożyła do wysuszenia na blasze kuchennego pieca rogowe grzebienie panny Lambercier. Jeden z nich w niewiadomy sposób został uszkodzony: wszystkie jego zęby były połamane. Ponieważ nikt nie wchodził do pokoju, w którym przebywał Rousseau, dorośli wywnioskowali, że musiał to być jego wybryk, i próbowali nakłonić go, by się przyznał do psoty.

Biorą mnie na spytki; zaklinam się, że nie ruszałem grzebienia. Państwo Lambercier wzywają mnie, napominaja, przypierają do muru, grożą wciąż przeczę. Poszlaki były wszelako zbyt silne i przeważyły wszystkie zaklęcia, mimo że pierwszy raz zdarzyło się spotkać u mnie z tak zuchwałym kłamstwem. Złośliwość, kłamstwo, upór, wszystko to było godne najsurowszej kary; ale tym razem nie panna Lambercier mi ją wymierzyła. Napisano do wuja; przybył. [...] Nie było sposobu wydobyć ze mnie wyznania. Brany na kilkanaście zawodów do kaźni i doprowadzany do najopłakańszego stanu, pozostałem niewzruszony. Byłbym przeniósł śmieć i byłem na nią zdecydowany. W końcu nawet siła musiała ustąpić wobec szatańskiego uporu dziecka: nie doświadczano już więcej mej stałości. Wyszedłem z okrutnej próby poszarpany na strzępy, ale tryumfujący.

Upłynęło blisko pięćdziesiąt lat od tej przygody i nie obawiam się już, aby mnie powtórnie ukarano; otóż, oznajmiam w obliczu nieba, że byłem niewinny. Nie złamałem ani nie dotykałem grzebienia, nie zbliżyłem się do blachy, nawet mi to w myślach nie postało. Niech nikt nie pyta, $w$ jaki sposób stała się szkoda; nie wiem i nie pojmuję; to jedno wiem, że nie ja byłem winny"29. "Od tej chwili przestałem się cieszyć niezmąconym szczęściem i czuję dziś jeszcze, że wspomnienie uroków dzieciństwa kończy się tutaj30.

rys [...] wyryty w sercu naszym przez Twórcę wszelkiej sprawiedliwości" (Emil, t. 1, 101, przypis autora).

${ }^{28}$ Stosunek Rousseau do koncepcji Locke'a to temat na obszerną rozprawę; tu warto jedynie nadmienić, że w Emilu, gdzie często odnosi się on do koncepcji pedagogicznych dawnych i współczesnych sobie autorów, Locke'owi przypada szczególne miejsce. Jego niektóre zalecenia zdrowotno-higieniczne znajdują uznanie u Rousseau, chociaż nie zgadza się on ze szczegółami ich przeprowadzania, inne, dotyczące rozwoju psychicznego dziecka i młodzieńca (kolejność etapów edukacji i zdolność przyswajania treści abstrakcyjnych) stają się przedmiotem jego mocnej krytyki; zob. np. Emil, t. 1, 84, 126, 140, 143; t. 2, 72-73.

${ }_{29}$ Wyznania, t. 1, 80-81, kursywa - JŻ.

${ }^{30}$ Tamże, 82. 
Dzieciństwo to nie dojrzało ${ }^{31}$ do swego naturalnego kresu, nie zdążyło się jeszcze wypełnić, kiedy jego bieg został przerwany przez wychowawców. Ilustrując swą koncepcję naturalnego rozwoju i wychowania chłopca przykładem własnego niepowodzenia rozwojowego, Rousseau tak oto opisał istotę swego przeżycia, a zarazem zagrożenia, na jakie wystawiane są kolejne pokolenia dzieci:

Niech sobie teraz czytelnik wyobrazi charakter nieśmiały i łatwy w życiu codziennym, ale żarliwy, hardy, niezłomny w uczuciach; dziecko zawsze prowadzone rozsądkiem, słodycza, wyrozumiałością, uprzejmościa, które nawet nie miało pojęcia o istnieniu niesprawiedliwości i które pierwszy raz doznaje jej, i to w tak straszliwej postaci, ze strony osób dotąd będących dlań przedmiotem czci i ukochania; co za przewrót! co za zamęt uczuć! co za wstrząs w sercu, w mózgu, w całej drobnej duchowej i moralnej istotce! $!^{32}$

Pobyt w Bossey trwał potem jeszcze kilka miesięcy, jednak nic nie było już takie samo:

przywiązanie, szacunek, ufność, swoboda wobec wychowawców zgasły. Nie patrzyliśmy już na nich jak na bogów, którzy czytaja w sercach; mniej wstydziliśmy się złych uczynków, a bardziej lękali posądzenia; zaczęliśmy się kryć, udawać, kłamać. Zwykłe przywary skaziły dawną niewinność i wdzięk naszych zabaw. Wieś nawet straciła $w$ naszych oczach urok słodyczy i prostoty; opustoszała i posępna, pokryła się jak gdyby oponą przesłaniającą jej pięknośćs ${ }^{33}$.

W eseju Rozprawa o naukach i sztukach ${ }^{34}$ Jean Starobinski interpretuje to wspomnienie Rousseau jako opis utraconego raju wzajemnej przejrzystości sumień, petnego zaufania i porozumienia ${ }^{35}$.

Odtąd dusze już się nie spotykają znajdując przyjemność w ukrywaniu się. Wszystko uległo zmąceniu, a ukarane dziecko doświadcza swej niepewności w poznawaniu drugiego, nad którą ubolewa pierwsza Rozprawa: «Tak więc nie będziemy wiedzieli, z kim mamy do czynienia». [‥] Przekleństwo pozoru, zerwanie łączności między ludźmi, kładzie

31 „Każdy wiek, każdy stan życia ma właściwą sobie doskonałość, rodzaj właściwej sobie dojrzałość. Często słyszeliśmy o człowieku skończonym; ale przyjrzyjmy się skończonemu dziecku: będzie to widok nowszy dla nas i, być może, nie mniej przyjemny". Emil, t. 1, 187. Zob. też przyp. 23.

32 Wyznania, t. $1,81$.

33 Tamże, s. 82, kursywa - JŻ.

${ }^{34}$ Jean Starobinski, Rozprawa o naukach i sztukach, w: tegoż, Jean-Jacques Rousseau. Przejrzystość i przeszkoda oraz siedem esejów o Rousseau, przeł. Janusz Wojcieszak (Warszawa: KR, 2000).

35 Tamże, 17. 
kres szczęśliwej jedności dziecięcego świata. Tę jedność trzeba będzie ponownie zdobyć, odzyskać.

Dziecięcy świat nie stanowi u Rousseau jedności. To dziecko, tak jak człowiek natury, jest „jednościa, całością bezwzględną"36, pozbawioną jeszcze sumienia ${ }^{37}$, nieznająca zaufania - nie jest ono przecież tym samym co ufność - tak samo jak nie zna porozumienia. Nie jest stroną relacji społecznych opartych na prawie i/lub sumieniu, ponieważ na razie wiedzione nakazem miłości siebie samego (amour de soi) żyje dla siebie, z nikim się nie porozumiewając i nie znajdując jeszcze żadnej przyjemności w "sspotkaniu dusz”. Ukarane tak, jak opisuje to Rousseau („,brany na kilkanaście zawodów do kaźni"), doświadcza nie tyle „swej niepewności w poznawaniu drugiego", gdyż obcowanie z innym opierało się dotąd na ufności, niczym vadium wnoszonej przez dziecko w obszar spotkania, co raczej „oburzenia, wściekłości, rozpaczy”38.

Oburzenie i wściekłość w reakcji na „okrucieństwo kary za zbrodnię, której nie popełnił" ${ }^{39}$ dwunastolatek, to afekty poruszające całe ciało. Rozpacz jednak jest uczuciem skrajnej bezsilności i braku nadziei na przyszłość, pojawiającym się w refleksyjnym umyśle, zdolnym porównywać, przewidywać i wnioskować. Nic nie wskazuje na to, aby Jean-Jacques mógł być szczególnie zaprawiony w tych rodzajach rozumowania. $\mathrm{W}$ jego pogmatwanych losach nie zaszło dotąd zdarzenie, na które nie mógłby odpowiedzieć ufnościa, a ta nie tylko nie wymaga, ale wręcz nie dopuszcza refleksji. Nie znaczy to, że się ona nie pojawiła; była jednak pochopna, chaotyczna i mocno zależna od emocji, targających dzieckiem przez cały czas trwania domowego dochodzenia.

Rousseau sądził, że nauka porównywania i wnioskowania zaczyna się u dziecka spontanicznie, gdy wiedzione ciekawością prowadzącą go wpierw do badania rzeczy w otoczeniu, zacznie zapoznawać się z szerszym światem przyrody. Jednak nawet na tym etapie jego siły fizyczne pozostają wciąż niewielkie, więc i refleksyjny rozum nie miałby jeszcze

36 Emil, t. 1, 14.

37 Ten brak dotyczy sumienia moralnego czy religijnego, rozumianego jako zdolność odróżniania dobra i zła, a więc zasadzającego się na abstrahowaniu, porównywaniu i refleksji. Dzieci władają "rozsądkiem zmysłowym”, "dziecięcym”, tworzą proste myśli w odniesieniu do licznych swoich wrażeń (zob. Emil, t. 1, 187), lecz nie rozumują. Ich sumienie (consciencia) jest odczuciem sprawiedliwości i niesprawiedliwości, bez rozważania ogólnej zasady tego, co sprawiedliwe lub nie, i odnoszenia jej do konkretnego zdarzenia.

${ }^{38}$ Wyznania, t. 1, 81. Gniew, nienawiść, oburzenie, wściekłość i rozpacz widoczne w reakcji niemowlęcia na „uderzenie dosyć lekkie, ale wymierzone z wyraźnym zamiarem skrzywdzenia go" przez mamkę, przekonują Rousseau, który obserwował to zdarzenie, o wrodzonym dziecku poczuciu sprawiedliwości i niesprawiedliwości (cytat z: Emil, t. 1, 52).

39 Wyznania, t. 1, 81. 
czego poskramiać. Do refleksji na temat relacji międzyludzkich, kwestii dobra i zła byłby zdolny i gotowy dopiero we wczesnym wieku młodzieńczym.

W biegu jego własnego losu kolejność ta została odwrócona. Nie będąc zdolnym do osądu ani poprzedzającej go refleksji, mając dotąd do czynienia z osobami, które czcił i kochał, wychowywany według reguł rozsądku, traktowany ze słodyczą, wyrozumiałością i uprzejmością, został oto postawiony przed trybunałem zimnej dociekliwości, której obce były rozsądek, wyrozumiałość i uprzejmość i która pozbawiała twarze kochanych osób właściwego im wyrazu, zmieniając je nie do poznania. To nie on nie rozumiał, że jest winny psoty, a przecząc - kłamstwa; to oni nie pojmowali (n'entendent) ani tego, co twierdził, ani tego, co widzieli naprzeciwko siebie $\mathrm{w}$ postawie jego ciała, $\mathrm{w}$ tonie głosu, spojrzeniu, ani nawet - co najgorsze - nie widzieli tego, kim był: szczerym, ufnym, naiwnym dzieciakiem. Ten rozum jakiś odmienny, który dotychczas pozwalał dorosłym i dzieciom wspólnie tworzyć harmonijną wspólnotę domową; wspól-wiedza, consciencia i przedrefleksyjne, holistyczne pojmowanie sytuacji jednym aktem umysłu (esprit), zostały u dorosłych zmrożone logiką ścisłego wnioskowania o faktach, a ich konieczne następstwo wskazywało państwu Lambercier jasno i wyraźnie, że kiedyś musi być „ten pierwszy raz" i że jest to właśnie ta chwila: oto dziecko spróbowało ich okłamać. Miejsce naturalnych uczuć, widocznych w nieskrępowanej ekspresji, zajęło właśnie uczucie wyrozumowane: u wychowawców podejrzliwość i zimna stanowczość w postanowieniu wytępienia wady dziecka, a u wychowanka rozpacz.

W Wyznaniach Rousseau w żaden sposób nie próbuje objaśnić przyczyn nagłej zmiany postępowania swoich opiekunów. Czytelnicy nie potrzebują wyjaśnienia. Szkicując w kilku akapitach treść i temperaturę przeżyć chłopca, któremu złupiono niewinność, i stawiając go przed czytelnikami w źle skrojonym kostiumie winowajcy, pozwala nam patrzeć na jego nowe położenie jego oczami. Widzimy wraz z nim, że państwa Lambercier jakby ktoś odmienił: właściwe im usposobienia przepadły, a ich miejsce zajął demon mechaniki, dowodzący, że nie mogło być skutku bez sprawcy, a ponieważ innych aktorów nie było w pobliżu, sprawcą jesteś ty. Obydwoje niczego innego nie żądali, jak tylko przyznania, że rozumowanie jest poprawne, a wniosek prawdziwy. Rozumiesz, co do ciebie mówimy? Więc potwierdź, przyznaj rację, przyznaj się. Stanowcze i niepojęte „nie!” Jeana-Jacques'a samo wymagało zrozumienia, a to szybko się znalazło: chłopak dopuścił się zuchwałego kłamstwa, objawił swą złośliwość i upór. Jednak jego „nie”, niedającego się nawet biciem zamienić $\mathrm{w}$ "tak", nie sposób wprost pojąć: cóż za szatański upór dziecka!

Może nie upór, a już zwłaszcza nie szatański, lecz zwykła i naturalna dziecięca niezdolność pokonania jednym skokiem dystansu, 
oddzielającego conscientia, bezpośredni, niezmącony wgląd i pewność co do siebie, myślenie obrazami, łączenie myśli-obrazów-rzeczy na zasadzie ich podobieństwa, następstwa po sobie, kojarzenia według nazw czy też innych reguł, wymienionych choćby przez Locke'a, od refleksyjnego myślenia pojęciowego?

Dbając o wychowanie moralne dziecka, pastor Lambercier wiedział zapewne, jak istotne jest wyplenienie w zarodku skłonności do kłamstwa, złośliwości i uporu w młodym umyśle i ze swej strony zrobił wszystko, by nie przeoczyć pierwszego momentu, w którym się te tendencje pojawią. Szczytny cel i wzniosła idea przesłoniły mu jednak rzeczywisty obraz duszy (esprit) wychowanka: swoje wysiłki podją przedwcześnie i skierował pod niewłaściwy adres. Odebrana stąd nauka pozwoliła dziecku odkryć, że ten przyjaciel Boga i znawca dusz wcale nie umie czytać w sercach. Jego rozum jest jakiś odmienny, skoro nie prowadzi do rozumienia tak prostych rzeczy, jak szczere "nie" dziecka, poparte łzami, zaklinaniem się i niezłomne wobec razów. Inteligencja uczuć, consciencia i owo pierwsze, naturalne pojmowanie, które każe niemowlętom rozpłakać się, gdy usłyszą płacz innych dzieci, nigdy nie pomyliłby się aż tak, jak potrafi się mylić drugi, nabyty wraz z językiem refleksyjny rozum rozumujący.

Tej właśnie wiedzy brak zdaniem Rousseau filozofom i autorom rozprawiającym o sposobach wychowania człowieka. Ich duszom daleko jest do „tej niebiańskiej i wzniosłej prostoty, której znamię przed wieki odcisnął na niej jej Stwórca, widać w niej już tylko rażący kontrast namiętności, która niby to rozumuje, i rozumu, który majaczy"40. Stan taki cechuje cały ród ludzki: im więcej zdobywamy wiadomości, tym mniej wiemy i pamiętamy o naszym właściwym zadaniu: o tym, by stać się człowiekiem. „Najmądrzejsi przykładają się do tego, co człowiek powinien wiedzieć, nie zwracając uwagi na to, czego dziecko może się nauczyć. Szukają zawsze w dziecku człowieka nie myśląc o tym, czym jest ono, zanim jeszcze stanie się człowiekiem"41.

Zanim dziecko stanie się człowiekiem, jako dzieło natury „istnieje wyłącznie dla siebie" ${ }^{\prime 2}$. Nie jest to egoizm, skoro istota taka, od urodzenia wrażliwa i z każdym dniem coraz śmielej poszukująca przyjemnych wrażeń, coraz silniej protestująca w obliczu wrażeń przykrych i bólu, nie wie niczego o sobie ani o swym istnieniu. Bez wątpienia jest ,jednościa, całością bezwzględna, która uznaje jedynie siebie albo kogoś podobnego do siebie. Człowiek społeczny jest tylko jednostką ułamkową, zależną od mianownika, i której wartość polega na stosunku do całości, jaką jest

\footnotetext{
40 Rousseau, Przedmowa do: Rozprawa o podstawach i pochodzeniu nierówności, 128.

${ }^{41}$ Emil, t. 1, kursywa - JŻ.

42 Tamże, 11.
} 
społeczeństwo"43. Dlatego „najistotniejszą naszą umiejętnością jest być człowiekiem”, pisze Rousseau i dodaje: „rzemiosłem, którego pragnę go nauczyć, jest życie" ${ }^{\prime 4}$.

Jak będzie przebiegać taka nauka? Z biegiem natury ${ }^{45}$, to znaczy: dobrze poznawszy „istotę, na którą trzeba działać"46, poprowadzi się ją do właściwego dla niej celu w sposób „odpowiedni dla człowieka i zastosowany do ludzkiego serca” ${ }^{47}$. „Przyroda chce, żeby dzieci były dziećmi, zanim będą ludźmi. Jeżeli zechcemy odwrócić ten porządek, wytworzymy owoce przedwczesne, które nie będą miały ani dojrzałości, ani smaku i zepsują się w krótkim czasie; będziemy mieli młodych uczonych i stare dzieci" ${ }^{\prime 8}$.

Dążąc do przywrócenia znaczenia źródłowego, intuitywnego pojmowania, do ukazania wartości przedrefleksyjnego, holistycznego rozumu i jego roli w kształtowaniu się samowiedzy (consciencia), której nie może zabraknąć „pełnemu człowiekowi”, Rousseau deprecjonował rozum refleksyjny w czasach, gdy filozofowie apelowali o jego rozwijanie, edukowanie i powszechne, samodzielne użytkowanie. Jego nie dość precyzyjnie formułowana koncepcja, przecząca zasadności Pascalowskiego rozdzielenia racji rozumu i serca ${ }^{49}$, stanowi śmiałą zapowiedź realizacji oświeceniowego wezwania „sapere aude!” 50 .

\section{Bibliografia}

Rousseau Jean-Jacques. 1782. Les Confessions. Texte du maniscrit de Genève. Édition du groupe «Ebooks libres et gratuits». Dostęp 24.03.2021. https:// www.google.com/search?q=JeanJacques+Rousseau \%2C+Les+Confessio ns $\% 2 \mathrm{C}+$ Texte+du+maniscrit+de+Gen\%C3\%A8ve+(1782)\%2C+\%C3\%89 dition+du+groupe+\%C2\%ABEbooks+libres+et+gratuits\%C2\%BB\&oq=JeanJacques+Rousseau $\% 2 \mathrm{C}+$ Les + Confessions $\% 2 \mathrm{C}+$ Texte $+\mathrm{du}+$ maniscrit+ de+Gen $\%$ C3\%A8ve+(1782) $\% 2 \mathrm{C}+\% \mathrm{C} 3 \% 89$ dition + du + groupe $+\% \mathrm{C} 2 \% \mathrm{AB}$ Ebooks+libres+et+gratuits\%C2\%BB\&aqs=chrome..69i57.7900814j0j1\&sourceid $=$ chrome\&ie $=$ UTF-8.

43 Tamże.

${ }_{44}$ Tamże, 15.

45 Zob. tamże, 4.

46 Tamże.

47 Tamże, 6.

48 Tamże, 85.

49 Zestawienie obydwu tych koncepcji to także temat, którego nie sposób omówić inaczej, jak w osobnej, obszernej rozprawie.

${ }^{50}$ Znajdujemy je w Kantowskiej rozprawie Co to jest oświecenie?, opublikowanej w 1784 roku, a więc już po śmierci Rousseau (1778). 
Rousseau Jean-Jacques. 1955. Emil czyli o wychowaniu, przeł. Wacław Husarski. Wrocław: Zakład imienia Ossolińskich, Wydawnictwo PAN.

Rousseau Jean-Jacques. 1956. Trzy rozprawy z filozofii społecznej, przeł. i oprac. Henryk Elzenberg. Warszawa: PWN.

Rousseau Jean-Jacques. 1956. Wyznania, przeł. i wstępem poprzedził Tadeusz Żeleński (Boy). Warszawa: PIW.

Rousseau Jean-Jacques. Discours-sur-l-origine-et-les-fondements-de-l-inegalite... Dostęp 21.02.2021. http://www.livrespourtous.com/e-books/detail/ Discours-sur-1-origine-et-les-fondements-de-1-negalite.../onecat/Livreselectroniques+Auteurs+R-a-Z+Rousseau,-Jean-Jacques/0/all_items.html.

Rousseau Jean-Jacques. Émile ou de l'education, Livre I, II et III. Dostęp 21.02.2021. http://www.livrespourtous.com/e-books/detail/Emile-ou-de-1-education---1/onecat/0.html.

Starobinski Jean. 2000. Jean-Jacques Rousseau. Przejrzystość i przeszkoda oraz siedem esejów o Rousseau, przeł. Janusz Wojcieszak. Warszawa: KR.

\section{Streszczenie}

W Wyznaniach, Emilu i w pismach filozoficzno-społecznych Rousseau szkicuje koncepcję mentalnego rozwoju człowieka, odbiegającą od oświeceniowego postulatu racjonalności i edukacji. W Emilu i w Wyznaniach zawarta została koncepcja wychowania, rozwijającego holistycznie wszystkie obszary umysłu. Rousseau kładzie w niej nacisk na harmonijny rozwój dyspozycji mentalnych dziecka, młodzieńca i młodego dorosłego, uwzględniający m.in. rolę i znaczenie consciencia, pre-racjonalnej świadomości, a zarazem wrodzonego poczucia sprawiedliwości. Koncepcja pedagogiczna i antropologiczna nakreślona w Emilu opiera się $\mathrm{w}$ dużym stopniu na własnych dziecięcych doświadczeniach opisanych przez Rousseau w Wyznaniach, torując też drogę dla koncepcji „wielorakiej inteligencji".

Słowa kluczowe: Rousseau, Emil, Wyznania, dziecko, rozum, inteligencja uczuć, consciencia, „inny rozum”, natura

\section{Jean-Jacques Rousseau: "some other, different kind of reason"}

\section{Summary}

In his Confessions, Emil, and philosophical and social writings, Rousseau sketches a mental human development concept that differs from the Enlightenment postulate of rationality and education. The Emil and the Confessions include the concept of education, holistically developing all areas of the mind. Rousseau emphasizes in it the harmonious development of mental dispositions of a child, 
adolescent and young adult, including the role and importance of consciencia, pre-rational awareness, and at the same time, an innate sense of justice. The pedagogical and anthropological concept outlined in the Emil builds heavily on his own childhood experiences as described by Rousseau in his Confessions and paves the way for "multiple intelligence".

Keywords: Rousseau, Emil, or On Education, The Confessions, child, reason, the intelligence of feelings, conscientia, "another reason", nature 